\title{
Academic psychiatry in the Deep South 1
}

\author{
Tariq Mahmood and Sarah Romans
}

\begin{abstract}
Summary To highlight the problems in the delivery of psychiatric services in rural New Zealand. We describe the innovative collaboration between the University of Otago Medical School in Dunedin and the Southland Hospital in Invercargill.

Clinical implications Forging of academic links between the regional medical schools and rural hospitals is one way of delivering specialist psychiatric services in rural areas.
\end{abstract}

Southland is the southernmost (latitude $46^{\circ}$ south) province of New Zealand. It covers an area of $34347 \mathrm{~km}^{2}$ consisting of pastoral lands, beautiful beaches, snow-covered mountains in the Southern Alps (see Figs $1 \& 2$ ) and fiords and rainforests in Fiordland. The population is a little over 100000, mostly of Scottish and Irish extraction. These families arrived in this remote corner of the Antipodes 150 years ago. Indigenous Maoris, who were the first to settle these areas constitute about $11 \%$ of the population. Roughly half of the population is concentrated in Invercargill, which is the main urban centre. Sheep and dairy farming are the main industries, however, Invercargill boasts of having the lone aluminium smelter in the country which utilises the power generated from the country's largest hydroelectric plant at Manapouri lake. Two hundred kilometres to the north is the city of Dunedin, a university town (population 115000) that is the centre of the province of Otago. The Otago Medical School, New Zealand's oldest medical school is established here (see Fig. 3), with Dunedin being the centre of regional and tertiary medical services. The regional forensic psychiatric centre is in Dunedin, as was the large psychiatric hospital, Cherry Farm Hospital, until its closure in 1992 when the community psychiatry movement landed, rather belatedly, on these shores.

'Presented at 'Rural Health - The Challenge Beyond the Year 2000', 14-16 May 1998, Invercargill, New Zealand.

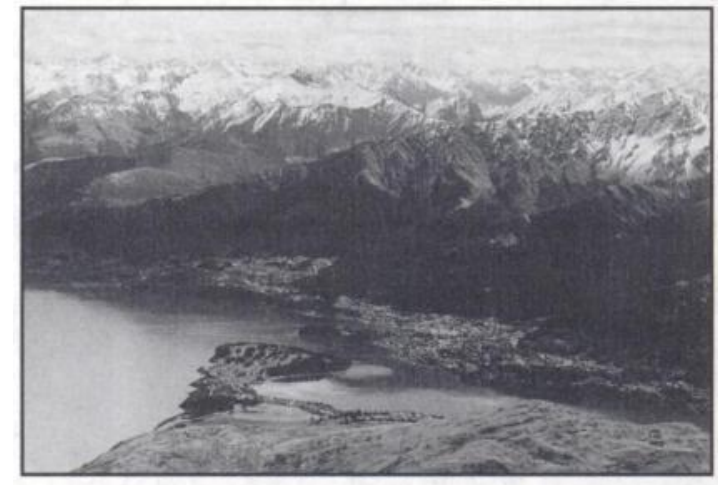

Fig. 1. Southern Alps, New Zealand

Southland had traditionally relied on Dunedin for the provision of psychiatric services, which is not unusual for rural New Zealand, or for that matter anywhere else in the world. The idea of a 'rural idyll' (Bonnar, 1995), where time stands still and medical problems are rare, is deeply ingrained in the consciousness of this hitherto predominantly agricultural nation. This is in sharp contrast to the reality. Romans et al (1990) in their study of rural women in New Zealand found a larger number of rural (31\%) than urban $(21 \%)$ women with a chronic health problem and more rural $(9.9 \%)$ than urban (6.5\%) women admitted to having problems with alcohol.

In 1969 a 40-bed psychiatric unit was added to the general hospital at Invercargill, however, the practice of transferring difficult cases, which practically meant all patients with psychosis, to Cherry Farm Hospital continued until its closure in 1992. Whereas Dunedin Psychiatric Services, being part of the teaching hospital, had minimal difficulty in recruiting and retaining psychiatrists, the unit in Southland was never able to obtain its full complement of eight psychiatrists. At its best, it functioned with a skeleton staff of two adult psychiatrists and one child psychiatrist. The closure of Cherry Farm Hospital meant more work for the already overburdened staff in Invercargill and without any appreciable increase in medical or administrative support, 


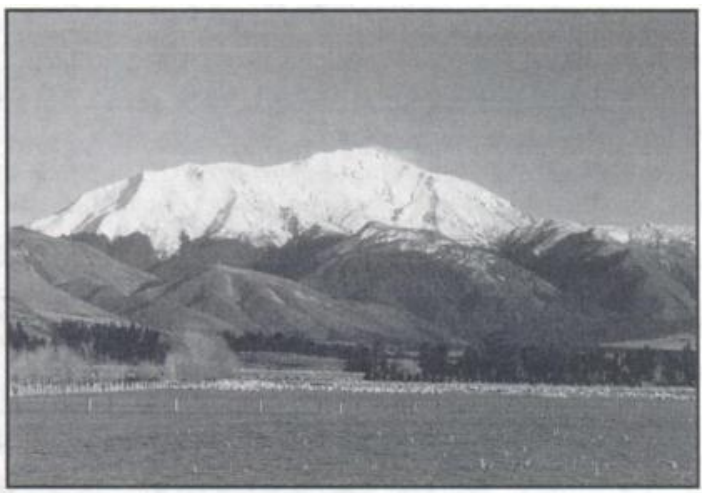

Fig. 2. Mount Hamilton, Southland, New Zealand

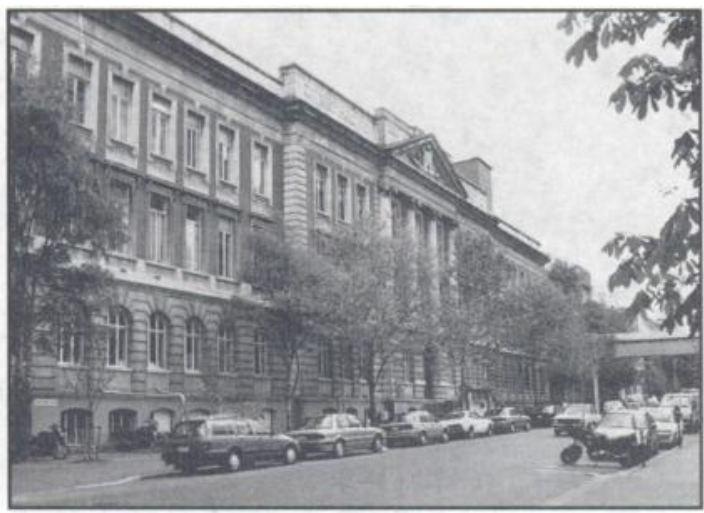

Fig. 3. Dunedin School of Medicine, New Zealand

it was not surprising that they felt unable to continue.

\section{The problem}

Southland Hospital's last general adult psychiatrist left in 1994 and the psychiatric staff from Dunedin Hospital made themselves available to provide once weekly cover for the in-patient unit. The out-patients were left to fend for themselves, those who could afford to travelled to Dunedin to see a psychiatrist at a private psychiatric hospital (Ashburn Hall-New Zealand's first private psychiatric hospital). Southland Hospital made concerted efforts to recruit psychiatrists, nationally and overseas, but to no avail. They could only recruit short-term locums from US, a very expensive and unsatisfactory stopgap arrangement.

\section{The solution}

It was during those weekly visits that some of the consultant staff from Dunedin realised that the development of the psychiatric unit in Invercargill as a satellite teaching centre might be a way of providing specialist psychiatric cover to this area. It was felt that the academic staff with joint clinical appointments would not feel professionally isolated and thus it would be easier to recruit and retain them. In this way the hospital would get the much-needed psychiatrists and the medical school would be able to provide community-oriented psychiatric teaching in a semiurban setting. It was envisaged that appointment of two senior lecturers would provide the nucleus that would attract other full-time psychiatrists.

\section{Progress to date}

The proposal was accepted by the management of Southland Hospital in 1996, however, it took another year before the first senior lecturer in psychological medicine was appointed (in January 1997) and the full complement was achieved in April 1997. The stage was set for teaching medical students as well as registrars. The first registrar was appointed in May 1997 and the first medical student was a trainee intern from Manchester (UK) who came for his elective in psychiatry. A regular run for trainee interns (sixth-year medical students) was established in November 1997 and the fifth-year medical students arrived in June 1998 to do their initial training in psychiatry.

An additional benefit of this collaboration has been to our research effort. Dunedin is well known for its bipolar register and research into mood disorders that we have begun to extend into the Southland. As anticipated, the hospital has started to engage full-time clinical psychiatrists on long-term contracts and recently we have attracted a child psychiatrist from Canada.

\section{Conclusion}

Delivery of modern high-tech medicine to sparsely-populated rural areas is neither easy nor cost-effective. Most governments have shied away from this challenge and tried to concentrate medical services and amenities in larger cities. This strategy is inequitable, as well as counterproductive, as it leads to people migrating from rural to urban areas. To prevent this downward spiral, the Otago Medical School has come up with a plan of decentralising the medical education. Under this scheme medical students will be placed in rural practices at an early stage of their career and for longer periods and to achieve this Dunedin Hospital and Southland will be linked 
with a rural network of smaller hospitals and general practitioner practices.

Petti et al (1987) reported on an innovative programme based on an affiliation between a psychiatry department at a major university and a rural public mental health facility. They found that seven out of 13 residents trained in this residency programme were working at least parttime in a rural practice. We are very hopeful that the affiliation between the Dunedin School of Medicine and the Southland Hospital will also prove to be equally successful in recruiting and retaining psychiatrists, and that some of the students and registrars trained in this programme will return to work in this area. This will go a long way in improving the delivery of psychiatric care in this remote corner of the world.

\section{References}

BonNar, C. B. (1995) Health needs of rural residents. Occasional papers: Royal College of General Practitioners, 71, 26-29.

Pett, T. A., Benswanger, E. G., Flalkov, M. J., et al (1987) Training child psychiatrists in rural public mental health. Hospital and Community Psychiatry, 38. 398-401.

Romans, S. E., Walton, V. A., Herbison, G. P., et al (1990) Psychiatric morbidity among women in urban and rural New Zealand: psycho-social correlates. British Journal of Psychiatry. 156, 84-91.

-Tariq Mahmood, Senior Lecturer, and Sarah Romans, Professor, Department of Psychological Medicine, Dunedin School of Medicine, University of Otago, PO Box 913, Dunedin. New Zealand

*Correspondence

\section{Evidence-Base Briefing: Dementia Claire Palmer}

The number of published papers on the subject of dementia is constantly rising and it is virtually impossible for clinicians to read everything available, let alone to

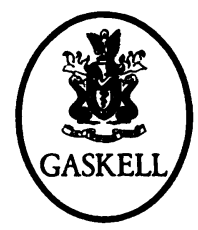
appraise it properly.

Evidence-Base Briefings (EBBs) are summarised collections of synthesised 'evidence' in a given topic area. This document on dementia attempts to encapsulate the best available evidence into a format which is quick and easy to use. Its main aim is to provide a checklist of appraised evidence from which a clinician can easily obtain original documents. These documents can then be appraised (using the tool provided) and interpreted for the clinician's own practice. The evidence sources on which the EBB is based include research, guidelines and national guidance. The EBB includes full references to its source documents and details of further information resources to support evidence-based practice.

June 1999, Paperback, ISBN 190124235 8, £15.00

Available from Book Sales, Royal College of Psychiatrists, 17 Belgrave Square, London SWIX 8PG

$\mathrm{Tel}+44$ (0) 1712352351 (extension 146) $9.30 \mathrm{am}-2 \mathrm{pm}, \mathrm{Fax}+44$ (0) 1712451231

http://wnw.rcpsych.oc.uk 